\title{
Strategi Peningkatan Tata Kelola Sistem Resi Gudang di Kabupaten Lombok Barat
}

\author{
Strategies to Improve the Governence of Warehouse Receipt System \\ In West Lombok Regency
}

\author{
Ni Made Wirastika Sari*, Muhammad Zubair, Anwar, Bambang Dipokusumo \\ Program Studi Agribisnis , Fakultas Pertanian, Universitas Mataram \\ Jalan Majapahit No 62, Gomong, Kecamatan Selaparang, \\ Kota Mataram, Nusa tenggara Barat, 83125, Telp: (0370) 621435 \\ *Corresponding Author Email: wirastikasari@unram.ac.id
}

Manuscript received: 08-12-2020. Accepted: 27-10-2021

\begin{abstract}
ABSTRAK
Sistem resi gudang (SRG) merupakan solusi yang dipersiapkan oleh pemerintah untuk mengatasi kendala pembiayaan yang dihadapi oleh para petani dalam mendapatkan bantuan pembiayaan atau permodalan. Namun, belum banyak petani yang memanfaatkan keberadaan SRG ini. Penelitian ini bertujuan untuk merekomendasikan strategi peningkatan tata kelola SRG di Kabupaten Lombok Barat. Penelitian ini dilakukan di Kabupaten Lombok Barat dengan pertimbangan di lokasi tersebut terdapat gudang yang dikelola oleh PT Pertani (Persero) yang terdaftar sebagai lembaga dalam Sistem Resi Gudang. Penelitian ini menggunakan data sekunder dan data primer. Data sekunder diperoleh dari studi literatur. Sedangkan data primer diperoleh dari hasil observasi langsung, wawancara mendalam dan dengan menggunakan kuesioner dengan para pakar. Data dalam penelitian ini dianalisis menggunakan analisis deskriptif dan perbandingan berpasangan dengan Analytic Hierarchy Process (AHP). Hasil penelitian ini menunjukan bahwa untuk meningkatkan tata kelola SRG di Kabupaten Lombok Barat, pemerintah harus berfokus dengan merekrut pengelola gudang yang profesional dan memiliki karakteristik kewirausahaan yang kuat.
\end{abstract}

Kata kunci: Analisis Hirarki Proses (AHP); Peningatan tata kelola; perbandingan berpasangan; sistem resi gudang; strategi

\footnotetext{
ABSTRACT

Warehouse receipt system (SRG) is a solution prepared by the government to overcome the financing constraints faced by farmers in obtaining financing or capital assistance. However, this program not widely used by farmer. The aimed of this research was to recommend strategies for improving SRG governance in West Lombok Regency. This research was conducted in West Lombok Regency with the consideration that there is a warehouse managed by PT Pertani (Persero) which is registered as an institution in the Warehouse Receipt System. This study uses secondary data and primary data. Secondary data were obtained from literature studies. Meanwhile, primary data obtained from direct observation, in-depth interviews and by using a questionnaire with experts. The data in this study were
} 
analyzed using descriptive analysis and pairwise comparison with the Analytic Hierarchy Process (AHP). The results of this study indicate that to improve SRG governance in West Lombok Regency, the government must focus on recruiting warehouse managers who are professional and have strong entrepreneurial characteristics.

Keywords: Improved Governance; Pairwise Comparison; Process Hierarchy Analysis (AHP); Strategy Warehouse Receipt System

\section{PENDAHULUAN}

Pemerintah memegang peranan penting dalam pengembangan produksi pangan, ketahanan pangan nasional dan kesejahteraan petani. Khususnya untuk komoditas unggulan seperti padi, jagung dan kedelai. Produktivitas padi rata rata dari seluruh provinsi di Indonesia pada tahun 2020 yaitu sebesar 51,14 ku/ha (BPS,2020). Salah provinsi di Indonesia yang juga memiliki produktivitas padi yang cukup tinggi yaitu provinsi NTB dengan produktivitas sebesar 48,12 ku/ha, dan mampu menghasilkan 1.309.759,50 ton gabah kering giling (BPS,2020). Jumlah ini masih belum maksimal. Peningkatan produktivitas padi ditentukan oleh banyak faktor seperti benih, kesuburan tanah, ketersediaan air, pupuk dan perawatan selama penanaman hingga panen. Kualitas benih padi yang ditanam memiliki faktor penting dalam penentuan jumlah gabah yang dihasilkan. Saat ini petani sudah sadar akan hal itu, sehingga petani lebih memilih membeli benih padi unggul bersertifikat daripada menyisakan hasil panen di musim tanam sebelumnya untuk dijadikan benih. Selain dikarenakan alasan prosesnya yang panjang, tidak adanya gudang khusus untuk menyimpan hasil panen musim tanam sebelumnya dan belum tentu benih yang mereka simpan tumbuh dengan maksimal, sehingga para petani lebih memilih membeli benih. Hal ini yang menyebabkan tumbuhnya industri perbenihan dan adanya petani penangkar benih. Petani ini khusus menanam padi untuk dijadikan benih bukan untuk konsumsi. Varietas padi yang banyak diproduksi di provinsi NTB yaitu inpari 32, ciliwung, ciherang, cigeulis dan mekongga.

Guna mendukung terciptanya industri perbenihan yang tangguh di NTB, pemerintah menugaskan kepada Balai Pengawasan dan Sertifikasi benih Pertanian (BPSB) Provinsi NTB untuk melaksanakan tugas teknis dinas pertanian dalam bidang perbenihan yaitu melaksanakan pembinaan mutu benih dengan fungsi melaksanakan penilaian kultivar, sertifikasi benih dan pengawasan pemasaran benih serta pengujian benih laboratories (BPSB NTB, 2018).

Tabel 1 Luas tanam, penggunaan benih dan persentase kesiapan benih di Provinsi NTB Tahun 2014 - 2018.

\begin{tabular}{lrrrr}
\hline Tahun & $\begin{array}{r}\text { Luas Tanam } \\
(\mathrm{Ha})\end{array}$ & $\begin{array}{r}\text { Kebutuhan Benih } \\
(\text { Ton })\end{array}$ & $\begin{array}{r}\text { Produksi Benih } \\
(\text { Ton) }\end{array}$ & $\begin{array}{r}\text { Persentase } \\
\text { Kesiapan }(\%)\end{array}$ \\
\hline 2014 & 432.480 & 12.974 .400 & $8.892,260$ & 68,54 \\
2015 & 447.489 & $13.424,670$ & $9.044,931$ & 67,38 \\
2016 & 464.366 & $13.930,980$ & $11.607,810$ & 83,32 \\
2017 & 475.242 & $14.257,260$ & $11.209,488$ & 78,62 \\
2018 & 479.994 & $14.399,800$ & $10.577,529$ & 72,98 \\
\hline
\end{tabular}


Berdasarkan Tabel 1, dapat dilihat kebutuhan benih padi sejak tahun 2014 terus mengalami peningkatan setiap tahunnya hingga tahun 2018. Namun produksi benih di NTB belum dapat memenuhi keseluruhan kebutuhan benih tersebut (BPSB NTB, 2018). Hal ini menunjukan jumlah kebutuhan benih padi unggul bersertifikasi yang tinggi belum sepenuhnya mampu dipenuhi dengan produksi benih padi unggul bersertifikasi di provinsi NTB.

Kesejahteraan petani menjadi hal penting yang perlu diperhatikan, karena jika petani tidak sejahtera hidupnya, kemungkinan mereka tidak mau menjadi petani dan beralih melakukan pekerjaan lain dan tidak ada lagi orang yang mau menjadi petani. Ini tentu akan menimbulkan efek domino yang panjang dan akhirnya akan mengancam ketersediaan bahan pangan untuk seluruh penduduk Indonesia. Program utama pembangunan pertanian adalah peningkatan ketahanan pangan. Salah satu upaya yang dilakukan pemerintah untuk mendorong peningkatan produktifitas padi dan meningkatkan kesejahteraan petani di Indonesia yaitu dengan mengeluarkan kebijakan - kebijakan di bidang pertanian dan undang - undang untuk memperkuat aturan- aturan yang telah dikeluarkan oleh pemerintah. Salah satu undang undang yang dikeluarkan pemerintah dalam hal ini yaitu Kementrian Perdagangan adalah undang - undang mengenai Sistem Resi Gudang (SRG).

Kegiatan produksi benih sering dihadapkan dengan terjadinya fluktuasi harga. Ketika musim panen raya, harga benih melemah. Para petani tidak dapat menahan harga komoditi pertaniannya lebih lama, karena petani membutuhkan uang untuk memenuhi kebutuhan hidupnya dan untuk modal menanam kembali pada musim tanam berikutnya. Sehingga petani menjual hasil panennya dengan harga yang sudah ditentukan oleh pedagang pengumpul. Hal ini membuat pendapatan petani menjadi tidak menentu dan tidak ada peningkatan kesejahteraan dalam kehidupan petani. Inilah yang menjadi keprihatinan pemerintah. Sehingga untuk mengatasi permasalahan tersebut, pemerintah dalam hal ini Kementrian Perdagangan melalui Undang - Undang No 9 Tahun 2006 yang kemudian diamandemen menjadi Undang Undang No 9 Tahun 2011 mengeluarkan instrumen Sistem Resi Gudang (SRG) sebagai solusi mengatasi jatuhnya harga komoditi saat panen (Bappebti, 2018). Penerapan SRG memungkinkan petani untuk menyimpan hasil panennya di dalam gudang ketika panen raya atau jumlah hasil panen melimpah dan harga komoditas hasil panen rendah hingga kondisi pasar mulai membaik. Selama waktu tunggu atau tunda jual tersebut, petani tetap berkesempatan memperoleh pembiayaan (maksimal 70\%) dari nilai barang yang disimpan melalui skema pembiayaan resi gudang ke lembaga keuangan, baik itu bank pemerintah maupun lembaga keuangan non-bank yang telah ditunjuk sebagai penyalur kredit resi gudang. Dengan adanya SRG ini diharapkan dapat meningkatkan kesejahteraan petani di Indonesia, khususnya petani skala kecil di Indonesia.

Secara keseluruhan, sampai dengan akhir tahun 2016 penerbitan Resi Gudang telah dilakukan di 76 kabupaten/kota yang tersebar di 21 propinsi. (Bappebti, 2016). Kabupaten Lombok Barat merupakan salah satu Kabupaten di provinsi NTB yang memiliki luas areal panen padi sebesar 30.841 hektar dengan rata rata produksi 51,82 ku/ha (BPS NTB,2014) dan di daerah ini terdapat terdapat satu gudang SRG yang dikelola oleh pihak swasta yaitu PT Pertani (Persero), yang berlokasi di Kecamatan Kediri, Kabupaten Lombok Barat, Nusa 
tenggara Barat. Gudang ini berfokus hanya penyimpanan gabah yang digunakan untuk benih sebagai komoditas yang di resi gudangkan.

Sejak tanggal 27 Agustus 2012 dengan nomor SK persetujuan 17/BAPPEBTI/KepSRG/SP/GD/09/2012 maka PT Pertani (Persero) resmi sebagai lembaga dalam sistem SRG. Sejak dikeluarkannya SK tersebut PT Pertani mengelola gudang milik swasta menjadi gudang SRG. Sejak ditunjuk menjadi lembaga dalam SRG, PT Pertani (persero) telah menerbitkan resi gudang dari bulan Oktober 2012 hingga akhir Juni 2015. Setelah itu hingga saat ini tidak pernah lagi menerbitkan resi gudang, padahal SK persetujuan menjadi lembaga dalam SRG masih berlaku dan tercatat di Bappebti. Sehingga peneliti melakukan penelitian mengenai "Strategi Peningkatan Tata Kelola SRG Di Kabupaten Lombok Barat" untuk menganalisis strategi peningkatan tata kelola SRG seperti apa yang dapat dilakukan di gudang SRG Lombok Barat ini, agar Gudang SRG Lombok Barat ini dapat dimanfaatkan oleh petani dengan sebagaimana mestinya. Oleh sebab itu penelitian ini dianggap penting untuk dilakukan.

\section{METODE}

Penelitian ini bertujuan untuk merekomendasikan strategi peningkatan tata kelola SRG di Kecamatan Kediri, Kabupaten Lombok Barat. Penelitian ini dilakukan di gudang SRG Lombok Barat dengan menggunakan data sekunder dan data primer. Data sekunder diperoleh dari studi literatur dan data primer diperoleh dengan wawancara mendalam dan penyebaran kuesioner perbandingan berpasangan kepada pakar. Data di analisis dengan menggunakan analisis deskriptif dan metode Analytic Hierarchy process (AHP) menggunakan software expert choice 11 .

Analytic Hierarchy Process (AHP) merupakan suatu alat bantu untuk mengambil keputusan yang mempertimbangkan banyak kriteria dan alternatif pilihan. Menurut Saaty, 2008 pemodelan masalah dalam AHP dilakukan dengan membuat struktur hierarki permasalahan dan menggunakan perbandingan berpasangan untuk membangun hubungan antar elemen dalam struktur hierarki tersebut. Prinsip kerja AHP adalah penyederhanaan persoalan yang kompleks, tidak terstruktur, menjadi bagian- bagian yang lebih sederhana dan mempercepat proses pengambilan keputusannya. Langkah awal dalam AHP yaitu dengan menentukan goal atau tujuan yang ingin dicapai dengan melakukan AHP, kemudian menentukan kriteria serta berbagai alternatif strategi yang dapat dilakukan. Proses pengisian kuesioner perbandingan berpasangan dan wawancara mendalam dilakukan terlebih dahulu untuk merumuskan kriteria dan faktor -faktor penentu keberhasilan implementasi SRG. Oleh karena itu pertanyaan wawancara mendalam lebih bersifat kualitatif. Melalui bantuan pakar, faktor - faktor tersebut akan dirangkum menjadi tiga kriteria penentu keberhasilan SRG (Tabel 2) dan tujuh faktor penentu keberhasilan SRG seperti yang ditunjukan pada Tabel 3.

Tabel 2 Proses perumusan tiga kriteria penentu keberhasilan SRG

\begin{tabular}{ll}
\hline Faktor penentu keberhasilan SRG & Sumber Acuan \\
\hline Kesiapan komoditas & Bappebti,2014 \\
Kesiapan gudang & Bappebti,2014 \\
Kesiapan kelembagaan & Bappebti,2014 \\
\hline
\end{tabular}


Tabel 3 Proses perumusan tujuh faktor penentu keberhasilan SRG

\begin{tabular}{ll}
\hline Faktor Penentu Keberhasilan SRG & Sumber Acuan \\
\hline Komitmen pemerintah daerah & BPPP, 2013; Kemendag, \\
& 2014; Agrifin, 2015; \\
Kelengkapan fasilitas dan atau infrastruktur gudang & BPPP, 2013; Agrifin, 2015 \\
Peningkatan produksi & BI, 2017; Kemendag,2014 \\
Kelembagaan yang terintegrasi & Kemendag, 2014 \\
Edukasi dan sosialisasi SRG & Balitbang Pertanian, 2013; \\
& BPPP, 2013; Fachruddin \\
& dan Rahayu, 2017 \\
Kemudahan dan kelancaran transaksi resi gudang & Balitbang Pertanian, 2013; \\
& Agrifin,2015 \\
Ketersediaan pasar lelang dan stanby buyer & Kemendag, 2014 \\
\hline
\end{tabular}

Perbandingan berpasangan dilakukan tepat setelah hirarki permasalahan disusun. Perbandingan berpasangan dilakukan dalam rangka menilai setiap level hirarki yang menjadi dasar dalam menentukan prioritas. Untuk membandingkan pasangan elemen dalam suatu level, skala perbandingan berpasangan akan digunakan. Skala ini terdiri atas angka 1 sampai 9 yang menggambarkan derajat kepentingan dan hubungan antar elemen. Matriks perbandingan berpasangan akan dibangun berdasarkan penilaian para pakar. Setelah penilaian terhadap pasangan elemen membentuk matriks perbandingan berpasangan, pembobotan dilakukan untuk menentukan ranking atau prioritas. Rangking atau prioritas dihitung dengan manipulasi matriks (Hafiyusholeh et al. 2015) .

Pakar yang dimaksud dalam AHP adalah orang - orang yang memiliki kapabilitas dan pengetahuan maupun pengalaman yang luas dan mendalam terhadap masalah yang ingin diselesaikan, seperti dalam penelitian ini yaitu untuk memastikan perumusan strategi yang tepat dalam peningkatan tata kelola SRG di Kecamatan Kediri, Kabupaten Lombok Barat. Kesahihan hasil penilaian para pakar yang menjadi responden dalam penelitian ini dapat dipastikan dengan menguji kosistensi penilaian para pakar melalui penghitungan consistency index (CI). Indeks konsistensi dikatakan baik apabila memiliki consistency ratio $(\mathrm{CR}) \leq 0,1$. Jika melebihi batas tersebut maka hasil penilaian dari para pakar perlu direvisi kembali. Perhitungan CR dapat dilakukan dengan rumus :

$$
\mathrm{CR}=\frac{C I}{R I} ; \operatorname{dimana} \mathrm{CI}=\frac{\lambda_{\max }-n}{n-1}
$$

Keterangan :

RI : random index (ketetapan dari Oarkridge Laboratory)

$\lambda_{\max }$ : nilai eigen maksimum

n : banyaknya alternatif

Dalam AHP penilaian yang objektif harus berdasarkan penilaian lebih dari satu orang pakar. Kemudian dilakukan pengecekan kosistensinya satu persatu. Penilaian atau pendapat yang konsisten akan digabungkan untuk di bobotkan. Penggabungan pendapat para pakar dilakukan melalui perhitungan rata- rata geometric dengan rumus seperti berikut : 


$$
\overline{x_{g}}=\left(\prod_{i=1}^{n} X_{i}\right) 1 / n
$$

Keterangan :

$\bar{X}_{g}:$ rata - rata geometric

$\mathrm{N}$ : jumlah pakar

$X_{i}$ : penilaian oleh pakar ke $-\mathrm{i}$

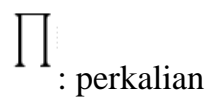

\section{HASIL DAN PEMBAHASAN}

\section{Pembobotan Kriteria}

Evaluasi keberhasilan implementasi SRG dapat dievaluasi dari sisi kesiapan komoditas, kesiapan gudang dan kesiapan kelembagaan. Ketiga hal tersebut harus dalam kondisi optimal guna menunjang keberlangsungan implementasi SRG di Kecamatan Kediri, Kabupaten Lombok Barat. Setelah dibobotkan dengan nilai CR 0.01, dapat diketahui bahwa kesiapan kelembagaan menempati posisi tertinggi dengan bobot 0,540 (Gambar 1).

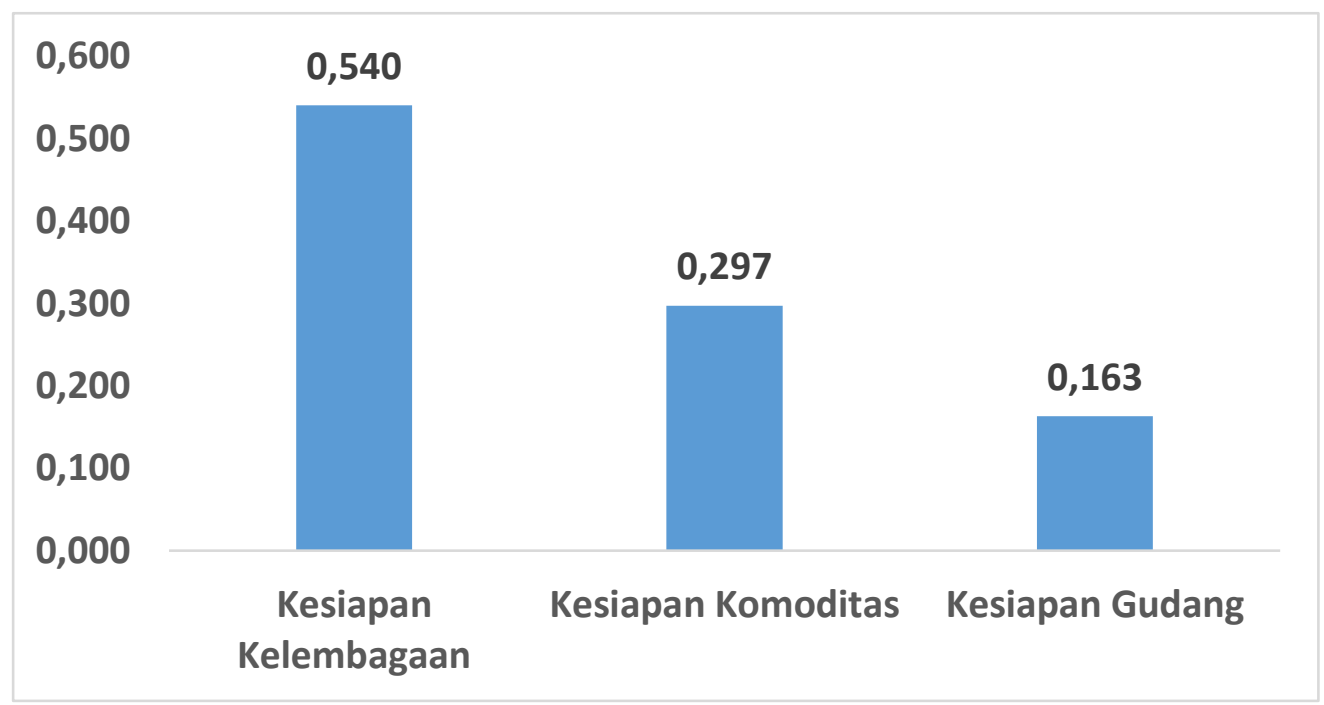

Gambar 1 Hasil pembobotan kinerja terhadap keberhasilan implementasi SRG

Sumber : Data diolah (2020)

Berdasarkan hasil penilaian tersebut maka pemerintah daerah selaku faslitator SRG di daerah harus memprioritaskan kesiapan atau kelengkapan kelembagaan serta fasilitas dan infrastruktur yang menunjang kegiatan SRG di Kabupaten Lombok Barat. Apabila kriteria kesiapan kelembagaan ini terpenuhi, maka jaminan keberlangsungan implementasi SRG sudah mencapai $54 \%$.

Kriteria selanjutnya adalah kesiapan komoditas, kriteria ini berada di urutan kedua yang pemenuhannya turut menentukan keberhasilan implementasi SRG sebesar 29,7\%. Kriteria ini ikut menetukan keberhasilan implementasi SRG karena komoditaslah yang menjadi objek utama dalam SRG. Komoditas yang akan di resi gudangkan harus memiliki daya simpan paling 
sedikit tiga bulan serta memenuhi standar mutu yang ditetapkan dan memenuhi jumlah minimum komoditi yang dapat diresigudangkan (Bappebti, 2017). Jumlah minimum komoditi yang dapat diresigudangkan tergantung pada kebijakan pengelola gudang. Pada gudang SRG Lombok Barat jumlah minimum yang dapat diresigudangkan yaitu 20 ton. Sehingga sangat penting untuk memberikan sosialisasi kepada para petani untuk memperhatikan standar mutu gabah untuk benih yang dihasilkan dan jumlah minimum komoditi tersebut agar dapat memenuhi persyaratan untuk di resi gudangkan. Berdasarkan persyaratan minimum jumlah yang dapat diresi gudangkan ini, tentu petani kecil yang hasil panenya dibawah 20 ton tidak bisa mengajukan resi gudang. Kendala ini juga yang menjadi salah satu penyebab petani secara perorangan belum banyak yang menggunakan SRG. Solusinya para petani mengumpulkan hasil panennya melalui koperasi, baru hasil panen tersebut diajukan untuk disimpan di gudang SRG Lombok Barat dan diresi gudangkan.

Kriteria selanjutnya yaitu kesiapan gudang dengan bobot sebesar 16,3\%. Kriteria ini penting karena jika gudang tidak siap untuk menampung komoditas yang sudah memenuhi standar mutu, daya simpan dan jumlah minimum untuk di resi gudangkan maka tentu keseluruhan proses SRG tidak akan berjalan. Jadi diperlukan integrasi antara kesiapan kelembagaannya, kesiapan komoditas dan kesiapan gudang sehingga implementasi SRG di Kabupaten Lombok Barat dapat berhasil.

\section{Pembobotan Faktor}

Evaluasi keberhasilan implementasi SRG dapat juga didasarkan pada beberapa faktor penentu. Pembobotan dilakukan guna melihat seberapa besar kontribusi masing - masing faktor terhadap keberhasilan implementasi SRG. Berdasarkan hasil pembobotan dengan nilai CR sebesar 0.1, diketahui bahwa Edukasi dan sosialisasi SRG menempati urutan pertama dengan bobot 0,343 dan faktor kemudahan dan kelancaran transaksi resi gudang menempati urutan kedua dengan bobot 0,197.

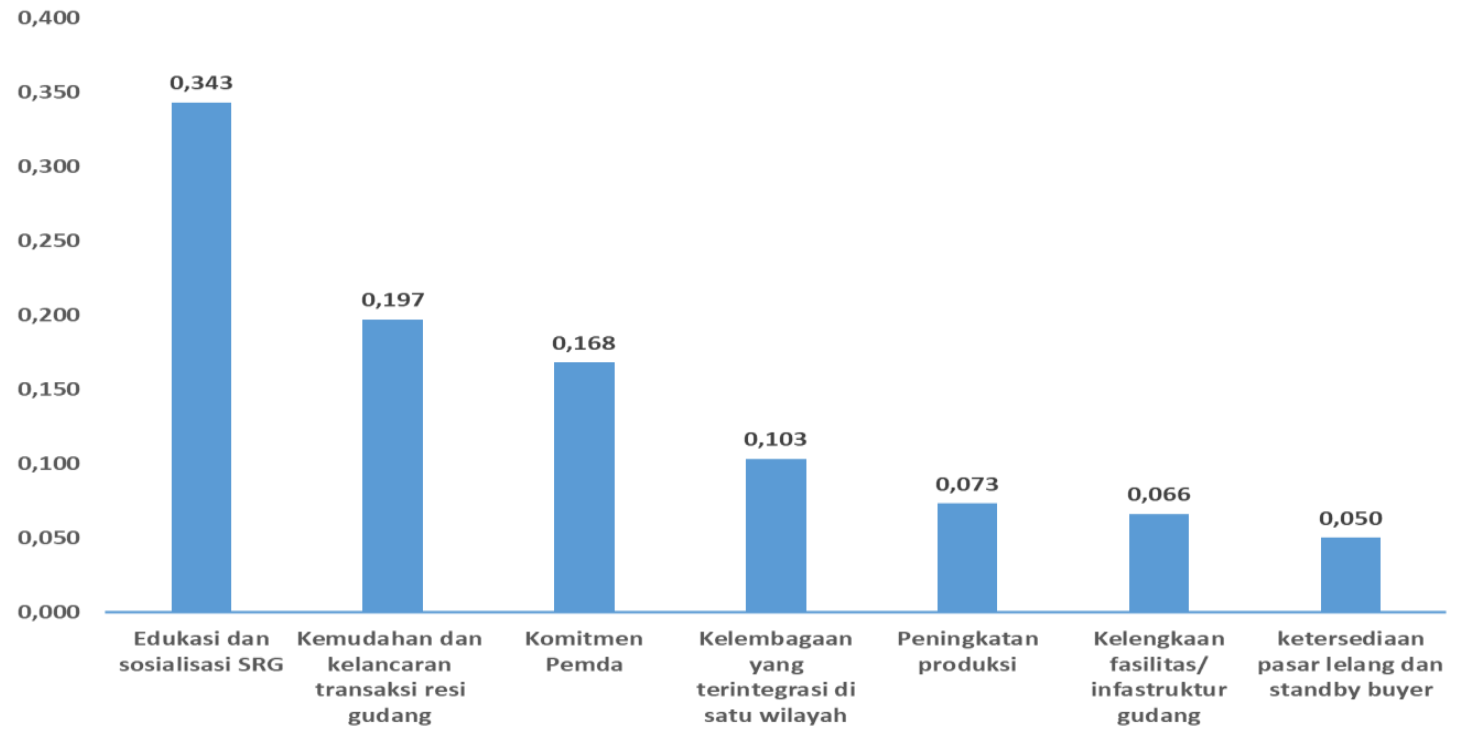

Gambar 2 Hasil pembobotan faktor terhadap keberhasilan implementasi SRG

Sumber : Data diolah (2020) 
Faktor edukasi dan sosialisasi SRG menempai urutan pertama sebesar 34,3\% karena salah satu penyebab belum dimanfaatkannya SRG oleh petani adalah karena kurangnya pemahaman petani mengenai SRG ini. Padahal jika petani paham dengan keseluruhan proses pengajuan SRG, manfaat yang diperoleh dengan menggunakan SRG tentu dapat meningkatkan pendapatan petani. Namun, dari hasil wawancara dengan petani diketahui bahwa alasan petani tidak mau menggunakan SRG karena mereka tidak mau melakukan tunda jual sebab mereka ingin segera mendapatkan uang dari hasil penjualannya. Ini menunjukan masih kurangnya sosialisasi dan edukasi SRG kepada petani. Edukasi dan sosialisasi SRG perlu dilakukan secara berkala dan berkelanjutan dan dalam kelompok kelompok kecil agar dapat memberikan hasil yang efektif. Menurut Fachruddin dan Rahayu (2018) keberhasilan SRG bergantung pada edukasi dan sosialisasi SRG terhadap pelaku usaha dalam hal ini juga termasuk petani. Temuan ini mengindikasikan perlunya pemerintah daerah mensinergikan program yang berkaitan dengan SRG dan mengintensifkan sosialisasi SRG kepada kelompok tani. Peningkatan pemahaman petani ini diharapkan akan dapat meningkatkan jumlah petani yang memanfaatkan SRG. Pada pelaksanaan SRG, partisipasi petani dapat dilakukan secara individu, dan dapat dilakukan secara kolektif melalui kelompok tani. Namun partisipasi melalui kelompok petani lebih direkomendasi karena dapat mempermudah proses penyimpanan komoditas hasil panen di SRG maupun pada proses mengakses pinjaman dari perbankan.

Faktor kemudahan dan kelancaran transaksi resi gudang menempati urutan kedua dengan kontribusi sebesar 19,7 \%. Hal ini berarti seluruh lembaga- lembaga yang terlibat dalam SRG harus aktif dan terkoordinasi dengan baik untuk mewujudkan transaksi resi gudang yang mudah dan lancar. Kemudahan dan kelancaran transaksi resi gudang perlu ditunjang oleh pemahaman yang baik dari keseluruhan lembaga - lembaga, dengan pemahaman yang baik akan prosedur yang tepat, peryaratan yang harus di terapkan maka tentu dalam pelaksanaannya akan lancar dan lebih mudah. Serta petani calon pengguna SRG pun perlu memahami prosedur dan prayaratan yang berlaku dalam SRG sehingga bisa mempersiapkan syarat syaratnya dan ini tentu akan mempercepat dan mempermudah dalam pelaksanaan SRG. Sehingga faktor utama dari keberhasilan implementasi SRG yakni perlu dilakukannya edukasi dan sosialisasi SRG kepada seluruh pihak yang terlibat.

Faktor lain yang menunjang kelancaran transaksi SRG yaitu komitmen pemerintah daerah. Faktor ini memiliki kontribusi sebesar 16,8 \% terhadap keberhasilan implementasi SRG. Pemerintah daerah memiliki peranan penting dalam keberhasilan SRG disuatu daerah melalui sosialisasi dan edukasi SRG kepada kelompok tani dan para pelaku usaha (BPPP, 2013; Fachrudin dan Rahayu, 2018). Melalui sosialisasi yang dilakukan pemerintah daerah para petani dapat mengetahui tentang SRG. Peran pemerintah daerah tidak hanya sebatas dalam memberikan sosialisasi saja, namun juga memiliki pera dalam membantu petani seperti memberikan subsidi bunga, kelengkapan sarana dan prasarana gudang, pendampingan.

Selanjutnya faktor kelembagaan yang terintegrasi disuatu wilayah memiliki kontribusi sebesar 10,3\% terhadap keberhasilan SRG. Hal ini penting karena dengan terintegrasinya kelembagaan di suatu wilayah administratif maka akan menghemat jarak, waktu, dan biaya sehingga akan mempercepat proses transaksi resi gudang. Faktor selanjutnya adalah peningkatan produksi sebesar yang berkonribusi sebesar 7,8\% terhadap keberhasilan SRG. 
Peningkatan produksi benih padi yang memenuhi syarat SRG penting untuk diprioritaskan, karena bila tidak memenuhi persyaratan SRG dari segi mutu, daya simpan dan jumlah minimum yang bisa diresi gudangkan, maka hasil panen tersebut tidak dapat di resi gudangkan.

Faktor kelengkapan fasilitas atau infrastruktur gudang berkontribusi sebesar 6,6\% dan ketersedian pasar lelang dan atau stanby buyer berkontribusi sebesar $6 \%$ terhadap keberhasilan implementasi SRG. Hal ini menandakan bahwa kedua faktor tersebut juga penting untuk diperhatikan dalam menunjang keberhasilan implementasi SRG, tanpa kelengkapan fasilitas gudang yang baik tentu akan dapat merusak komoditas yang disimpan di dalamnya misalnya karena lembab, serangan kutu ataupun tikus. Kemudian kelengkapan fasilitas gudang lainnya seperti lantai jemur, mesin air screen cleaner (mesin untuk pembersih gabah/benih padi) ini sangat penting juga untuk menunjang keberhasilan benih yang memenuhi standar SRG. Selanjutnya ketersedian pasar lelang atau stanby buyer juga penting karena dengan adanya pasar lelang atau stanby buyer akan member rasa tenang petani yang melakukan resi gudang bahwa benihnya pasti aka ada yang membeli . Dalam SRG di Kabupaten Lombok Barat ini PT Pertani (Persero) juga bertindak sebagai stanby buyer. Jadi jika petani pemiliki resi gudang setuju barang yang di masukan ke resi gudang akan dibeli oleh PT Pertani (Persero), jika tidak, petani pemilik resi gudang dapat meminta bantuan pengelola gudang untuk menjualkan benihnya ke pasar lelang.

\section{Pembobotan Alternatif Strategi}

Pengurutan skala prioritas strategi dilakukan dengan bantuan AHP. Berdasarkan hasil analisis dengan nilai CR sebesar 0.06. Urutan tertinggi prioritas strategi peningkatan tata kelola SRG di Kabupaten Lombok Barat adalah dengan merekrut pengelola gudang yang professional dan memiliki karakteristik kewirausahaan yang kuat.

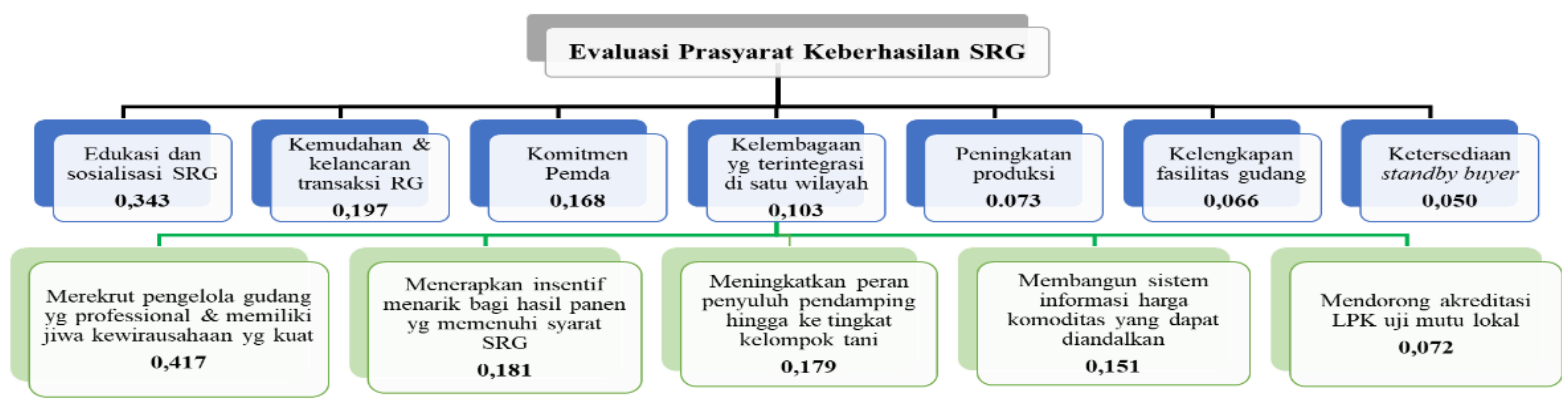

Gambar 3 Hasil pengolahan AHP terhadap alternatif strategi

Sumber: Data diolah (2020)

Merekrut pengelola gudang yang profesional dan memiliki karakteristik kewirausahaan yang kuat merupakan startegi prioritas dan bersifat mendesak yang harus dilakukan, mengingat perannya yang sangat penting terhadap keberhasilan implementasi SRG di kecamatan Kediri,Kabupaten Lombok Barat. Hasil ini juga sesuai dengan hasil analisis sebelumnya bahwa kesiapan kelembagaan paling berkontribusi terhadap keberhasilan implementasi SRG. Pengelola yang ditunjuk harus profesional, sehingga dapat melayani petani dengan baik dan 
memastikan pelaksanaan SRG tepat sasaran dengan memprioritaskan layanan kepada petani. Pengelola gudang harus beperan aktif memfasilitasi dan mengajak petani untuk memanfaatkan layanan SRG. Karakteristik kewirausahan itu sendiri meliputi karakeristik individu dan karakteristik psikologis. Karakteristik individu yaitu usia, pendidikan, pengalaman, kekosmopolitan (Cassons, 2006; Muharastri, 2013, Sumantri, 2013). Sedangkam karaktersitik psikologis meliputi berani mengambil risiko, toleransi terhadap ketidakpastian, innovatif, mandiri, bertanggung jawab (Basrowi, 2011; Danarti, 2012; Hasbulah dan Sulaeman, 2012). Keseluruhan karakteristik tersebut berpengaruh positif dan signifikan terhadap kinerja usaha. Sehingga penting untuk merekrut pengelola gudang juga harus memiliki karakteristik kewirausahaan yang kuat yang dapat meningkatkan produktivitas personal yang mempengaruhi kinerjanya dan menentukan keberhasilan usaha (Sari et al, 2016)

Strategi kedua yaitu memberikan insentif bagi petani yang hasil panennya memenuhi syarat SRG dari segi standar mutu, daya simpan dan jumlah minimum untuk di resi gudangkan. Hal ini dilakukan untuk menstimulus petani mau menghasilkan benih yang berkualitas dan petani mau memanfaatkan fasilitas layanan SRG di daerahnya. Strategi di urutan ketiga yaitu meningkatkan peran penyuluh pendamping hingga ke tingkat kelompok tani di desa. Sebab selama ini penyuluhan hanya dilakukan sampai tingkat kecamatan dalam forum dengan skala besar. Bagi petani, khusunya petani dalam skala kecil, penyuluhan dalam kelompok kecil akan lebih efektif karena dapat meningkatkan kepercayan diri petani untuk bertanya dan berdiskusi dengan penyuluh/narasumber.

Strategi selanjutnya yang menempati posisi keempat dan kelima yaitu membangun sistem informasi harga komoditas yang dapat diandalkan serta mendorong akreditasi LPK uji mutu lokal. Sistem informasi harga komodias yang dapat diandalkan dan mudah diakses oleh petani akan memudahkan petani dalam mengambil keputusan saat yang tepat harus menyimpan hasil panenenya di gudang dan saat yang tepat untuk menjual hasil panennya. Selanjutnya startegi mendorong akreditasi LPK uji mutu lokal ini dapat dipertimbangkan untuk dilakukan saat SRG Lombok Barat sudah stabil sdan banyak dimanfaatkan oleh petani di Lombok Barat sehingga dengan adanya LPK uji mutu lokal akan mempercepat proses resi gudang.

\section{KESIMPULAN}

Perumusan strategi tata kelola SRG Gudang Lombok Barat harus difokuskan pada edukasi dan sosialisasi SRG. Urutan prioritas strategi peningkatan tata klola SRG dimulai dengan merekrut pengelola gudang yang profesional dan memiliki karakteristik kewirausahaan kuat. Lalu memberikan insentif bagi hasil panen yang memenuhi syarat SRG, meningkatkan peran penyuluh pendamping hingga ke tingkat kelompok tani, membangun sistem informasi harga komoditas yang dapat diandalkan dan terakhir adalah mendorong akreditasi uji mutu lokal.

\section{Ucapan Terimakasih}

Peneliti mengucapkan terima kasih kepada LPPM Universitas Mataram atas dana yang diberikan melalui sumber dana DIPA BLU skema Penelitian Dosen Pemula Universitas Mataram tahun Anggaran 2020 dengan nomor kontrak 2770/UN18.L1/PP/2020 


\section{DAFTAR PUSTAKA}

[Agrifin] Agriculture Finance Support Facility. 2015. Warehouse Receipt Financing. The Experience of Access bank madagascar. Washington, DC (US): World Bank.

[Balitbang Pertanian] Badan penelitian dan pengembangan Pertanian. 2013. Kajian Efektivitas Sistem Resi Gudang Dalam Stabilitas pendapatan Petani. Jakarta (ID): Balitbang Pertanian.

[Bappebti] Badan Pengawas Perdagangan Berjangka Komoditi. 2017. Annual report Tahun 2016. Jakarta (ID): Bappebti.

[BI] Bank Indonesia. 2017. Kajian Pilot Project Peningkatan Manfaat Sistem resi Gudang (SRG). Jakarta(ID): BI.

[BPS] Badan Pusat Statistik. 2016. Luas panen dan produksi Padi berdasarkan provinsi di Indonesia. 2015. Jakarta (ID): BPS.

[BPPP] Badan Pengkajian dan Pengembangan Perdagangan. 2013. Analisis Efektifitas

Implementasi Sistem Resi Gudang (SRG) Komoditi Jagung. Jakarta (ID) : Pusat

Kebijakan Perdagagan Dalam Negeri.

[Kemendag] kementrian Perdagangan. 2014. Analisis Implementasi Sistem Resi Gudang Komoditi Lada. Jakarta (ID): Kemendag.

Bappebti.2010. PT Pertani sebagai standby buyer komoditi gabah dan beras pada sistem resi gudang. Diakses pada tanggal $10 \quad$ Oktober 2020. http://website.bappebti.go.id/id/news/press_release/detail/188.html.

Basrowi. 2011. Kewirausahaan Untuk Perguruan Tinggi. Bogor (ID): Ghalia Indonesia.

Danarti. 2012. Analisis Potensi dan Kebutuhan Pengembangan Kewirausahaan di Pusat KTM Telang. Jakarta (ID): Kementrian Tenaga Kerja dan Transmigrasi.

Fachruddin, Ahmad dan Lestari Rahayu. 2017. Evaluasi Prasyarat keberhasilan Sistem Resi Gudang di Kabupaten Bantul. AGRARIS: Joural of Agribusiness and Rural development Research.3 (2), 7-17.

Fadhiela, K., Rachmina, D., \& Winandi, R. (2018). Biaya Transaksi dan Analisis Keuntungan

Petani pada Sistem Resi Gudang Kopi Arabika Gayo di Kabupaten Aceh Tengah. Jurnal Agribisnis Indonesia, 6(1), 49-60.

Hafiyusholeh, M., Asyhar, A. H., \& Komaria, R. (2015). Aplikasi Metode Nilai Eigen Dalam Analytical Hierarchy Process Untuk Memilih Tempat Kerja. Jurnal Matematika" MANTIK", 1(1), 6-16.

Hasbullah R, Sulaeman E. 2012. Pembinaan Karakter Wirausaha Mahasiswa Melalui Metode Pelatihan Soft skill di Fakultas Ekonomi Uniska. Banjarmasin (ID): Jurnal Manajemen.

Listiani N, Haryotejo B. 2013. Implementasi sistem resi gudang pada komoditi Padi: studi kasus di kabupaten Tuban, Provinsi Jawa Timur. Buletin Ilmiah Litbang Pertanian. 7(2): 193-211.

Muharastri Y. 2013. Karakteristik Wirausaha, Kompetensi Kewirausahaan dan Kinerja Usaha Peternakan Sapi Perah di KTTSP Kania Bogor. [tesis]. Bogor (ID): Institut Pertanian Bogor. 
Sari AN, Yuliawati. 2019. Faktor - faktor yang mempengaruhi respon petani garam tentang sistem resi gudang di Desa Raci kecamatan batangan. Journal on Socio-Economics of Agriculture and Agribusiness (SOCA). 13(1): 1-13.

Sari, Ni Made Wirastika, Heny K. Suwarsinah, and Lukman M. Baga. "Pengaruh karakteristik kewirausahaan terhadap kinerja usaha mikro, kecil dan menengah (UMKM) Gula Aren di Kabupaten Lombok Barat." Jurnal Penyuluhan 12.1 (2016). Cassons M. 2006. The Oxford Handbook of Entrepreneurship. New York (NY): Oxford University Press.

Sumantri B. 2013. Pengaruh Jiwa Kewirausahaan terhadap Kinerja Usaha Wirausaha Wanita pada Industri Pangan Rumahan di Bogor. [tesis]. Bogor (ID): Sekolah Pascasarjana Institut Pertanian Bogor. 